\title{
PNEUMATIKUS MUNKAHENGEREK SPECIÁLIS ALKALMAZÁSA
}

\author{
Filepkó Máté \\ BSc géptervezö hallgató, Miskolci Egyetem, Gép-és Terméktervezési Intézet \\ 3515 Miskolc, Miskolc-Egyetemváros, e-mail: filepko.mate@ gmail.com \\ Bihari János \\ egyetemi docens, Miskolci Egyetem, Gép- és Terméktervezési Intézet \\ 3515 Miskolc, Miskolc-Egyetemváros, e-mail: machbj@uni-miskolc.hu
}

\begin{abstract}
Absztrakt
Az Aventics Hungary Kft. már tizenkettedik éve rendezi meg a Nemzetközi Aventics Pneumobil versenyt, melynek keretein belül, süritett levegövel hajtott pneumobilok tervezése és épitése a feladat. A versenysorozatban, csapatommal a Miskolci Egyetemet képviselve részt vettünk az idei versenyen is. Pneumobilokon, az elsö feladat, melyet meg kell oldanunk, az a munkahengerek alternáló mozgásának forgó mozgássá való átalakitása. Erre a célra terveztem egy egyedi fogaskerék-fogasléc hajtómüvet, mely évek óta pneumobilunk szive.
\end{abstract}

Kulcsszavak: hajtómü, pneumobil, pneumatikus

\begin{abstract}
The Aventics Hungary Ltd. has organized the twelfth International Aventics Pneumobile Competition, which includes the design and construction of pneumatic-drive. We participated in this year's competition, with my team at the University of Miskolc. In pneumobiles, the first task to be solved is to convert the alternating motion of the cylinders into rotary motion. I designed this for this purpose, a unique gear rack-gear unit that has been the heart of our pneumobile for years.
\end{abstract}

Keywords: gear unit, pneumobil, pneumatic

\section{Bevezetés}

A mérnöki tanulmányok során gyakran találkozunk olyan feladattal, ahol valamilyen mozgás továbbítása a feladat. Kevésbé gyakoriak az olyan feladatok, ahol a mozgások átalakítása a cél. A pneumobil versenysorozatban az elsődleges feladat egy munkahenger lineáris mozgásának forgómozgássá alakítása. Bár a hétköznapokban is nagyon sok megoldással találkozhatunk, ki kellett választanunk azt, amely a leghatékonyabb a pneumatikus munkahengerek esetében. További nehézséget okoz, hogy a pneumobilokban a munkahengerek használata is eltérhet a megszokottól. Így esett a választás a fogaskerék-fogasléc hajtómüre, mely jobb hatásfokkal valósítja meg ezt a mozgásátalakítást, mint a forgatytyús mechanizmus, ezen kívül az erőátadása is kedvezőbb.

\section{Mi a pneumobil [1]?}

Pneumatikus jármü, amely a sủrített levegő energiáját alkalmazva, a pneumatikus vezérlő és végrehajtó elemek által kifejtett erőből nyomatékot állít elő a hajtott kerékre vagy kerekekre [4]. Ezek a 
pneumobilok az Aventics Hungary Kft. által 2008 óta minden évben megrendezett nemzetközi Pneumobil versenyére készülnek, ahol több ország mérnökhallgatói által konstruált járművekkel versenyezhetnek. Egyetemünk is rendelkezik több pneumobil csapattal, mely csapatok minden évben képviselik az Alma Matert [5], [6], [7]. Vezetésemmel az AirMEks pneumobil csapat idén 5. alkalommal fog részt venni a versenysorozatban.

\section{A munkahengerek [2] [3]}

A munkahenger egy olyan energiaátalakító eszköz, amely a bele áramló közeg nyomási energiáját alakítja át lineáris vagy forgó mozgássá. A közeg lehet sủrített levegő vagy hidraulikaolaj (esetleg más folyadék).

Gáz halmazállapotú közeg használata esetén pneumatikus munkahengerekről, míg folyadék halmazállapotú közeg esetén hidraulikus munkahengerekről beszélünk. A két különböző múködtető közeg egyben meghatározza a munkahenger kialakítását és az alkalmazási területét is.

A sürített levegő összenyomhatóságából, gyorsabb áramlási sebességéből adódóan a munkahenger kialakítása egyszerübb és olcsóbb, nagy sebességekre képes, de kisebb erők kifejtésére alkalmas. A hidraulika olaj viszont ezzel szemben nem összenyomható, lassabb áramlású és környezetre is veszélyes, emiatt a munkahenger kialakítása robusztus és nagyon drága, kisebb mozgási sebességekre képes, de hatalmas erők kifejtésére alkalmas, melyet nem csak mozgás közben, hanem inaktív állapotban is képes tartani.

\subsection{A munkahengerek müködési elve [2] [3]}

A munkahenger belsejébe áramló közeg nyomási energiája a dugattyú felületére nyomást gyakorol, majd az ebből származó erő azt mozgásba hozza. A dugattyú mozgásának iránya attól függ, hogy melyik oldalról lesz nagyobb ez az erő, természetesen a mozgás irányával szemben levő kamra tartalmát hagyni kell kifelé áramolni. Az erő felírható az (1) egyenlettel:

ahol:

$$
\mathbf{F}=\mathbf{p} * \mathbf{A}
$$

$$
\begin{aligned}
& \text { F: erő }[\mathrm{N}] \\
& \text { p: nyomás }[\mathrm{MPa}] \\
& \text { A: felület }\left[\mathrm{mm}^{2}\right]
\end{aligned}
$$

Az egyoldali dugattyúrúd-kivezetéses munkahenger esetén a dugattyú felülete a dugattyúrúd felőli oldalon kisebb (a dugattyúrúd által lefedett keresztmetszet miatt), ha tehát a két kamara nyomása azonos, akkor a dugattyúrúd kifele mozog. A különböző felület jól használható, mivel vannak olyan esetek, amikor csak az egyik irányban fontos a kifejtett erő nagysága (pl. prések, ahol csak a nyomás kifejtése fontos, a visszahúzás csak annyira, hogy elemelkedjen a munkadarabtól), a differenciál munkahenger pedig pontosan kétszer akkora erőt tud kifejteni a dugattyú kifelé mozgása közben, mint a másik irányban.

A dugattyúrúd nélküli és az átmenő dugattyúrudas munkahengerek esetén a nyomás által kifejtett erő mindkét irányban (az azonos felület miatt) azonos. 


\subsection{Egy pneumatikus munkahenger metszeti képe és elemei}

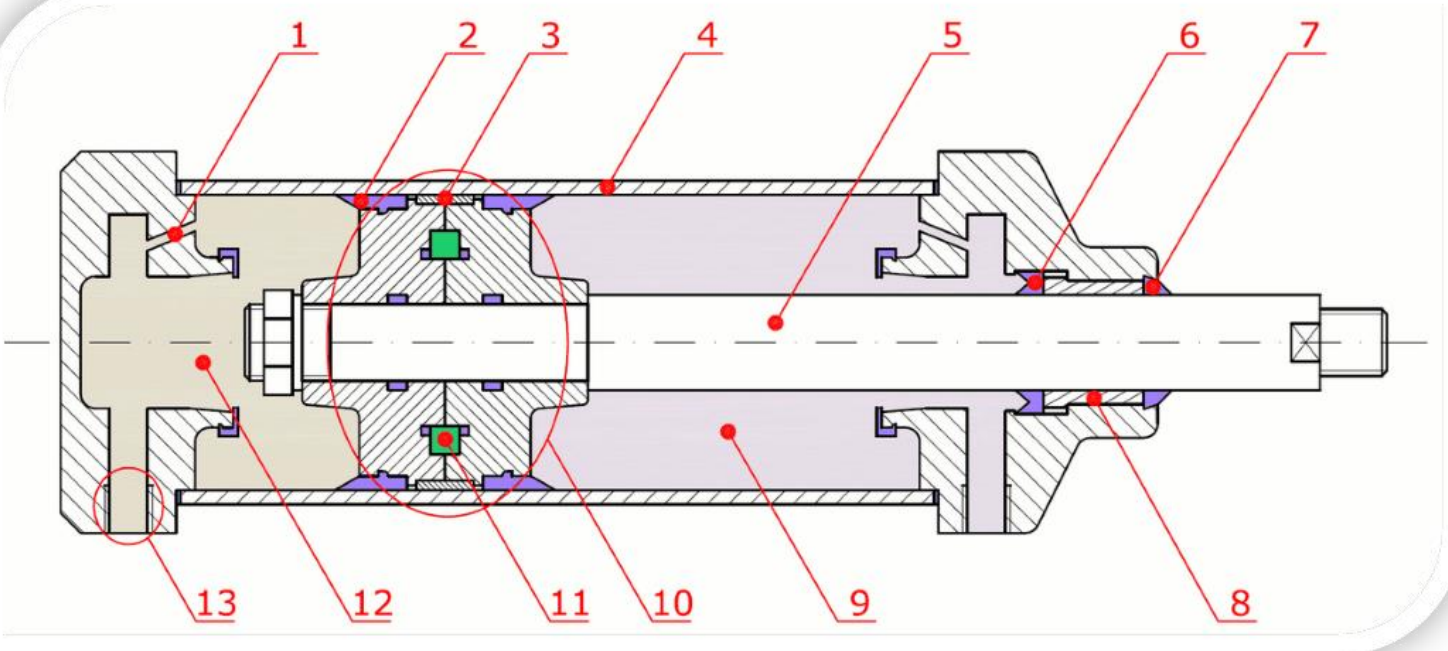

1. ábra. Egy pneumatikus munkahenger fö részei

1. táblázat. A pneumatikus munkahenger részei

\begin{tabular}{|c|c|c|}
\hline Tételszám & Megnevezés & Megjegyzés \\
\hline 1. & véghelyzet-csillapítás & $\begin{array}{l}\text { kis átméröjü furat, melyen keresztül a közeg áramlása fojtást szenved, ezzel a } \\
\text { dugattyú mozgását a véghelyzet közelében lefékezi }\end{array}$ \\
\hline 2. & tömítés & megakadályozza a két kamra között a közeg szivárgását \\
\hline 3. & csúszógyürü & $\begin{array}{l}\text { - a dugattyú megvezetésére szolgál } \\
\text { - } \quad \text { puha fém, esetleg teflon } \\
\text { - finoman megmunkált külső palást }\end{array}$ \\
\hline 4. & henger, elölap és hátlap & \\
\hline 5. & dugattyúrúd & $\begin{array}{l}\text { - } \quad \text { a dugattyú mozgását közvetíti a müködtetendő berendezés felé } \\
\text { - } \quad \text { felülete finoman megmunkált }\end{array}$ \\
\hline 6. & ajakos tömítés & tömítés alakja olyan, hogy a közeg nyomása ráfeszíti a tömítendő felületre \\
\hline 7. & szennylehúzó gyürü & a dugattyúrúd felületére kívülröl rákerülő szennyeződések ellen véd \\
\hline 8. & csúszógyürü & $\begin{array}{ll}\text { - } & \text { dugattyúrúd megvezetésére szolgál } \\
\text { - } & \text { finoman megmunkált felület és puhább anyagminőség jellemzi }\end{array}$ \\
\hline 9. & első kamra & ha e kamra nyomása nagyobb, akkor a dugattyúrúd balra mozog \\
\hline 10. & dugattyú & $\begin{array}{l}\text { - } \quad \text { a henger belső terének felosztása } \\
\text { - } \quad \text { a dugattyúrúd keresztmetszeténél nagyobb felület biztosítása }\end{array}$ \\
\hline 11. & állandó mágnes & a házra kívülről szerelt érzékelők számára jelzi a dugattyú helyzetét \\
\hline 12. & hátsó kamra & ha e kamra nyomása nagyobb, akkor a dugattyúrúd jobbra mozog \\
\hline 13. & menetes furat & $\begin{array}{l}\text { - } \quad \text { itt áramlik be és ki a közeg } \\
\text { - menetes csatlakozás }\end{array}$ \\
\hline
\end{tabular}




\section{A hajtáslánc}

A pneumobilunk hajtását egy pneumatikus hajtáslánc biztosítja, mely egy munkahengerből és egy hajtómüből áll. Ez a hajtómü kompakt, könnyü és megbízható konstrukció. Ideális egy pneumobil meghajtására. A verseny során egy pneumatikus munkahenger erejét hasznosítva kell meghajtanunk a jármüvet. A lineáris mozgást, a toló és húzóerőt egy fogaskerék-fogasléc hajtómüvet használva (amely az egyirányúsítást is megvalósítja) alakítjuk át forgómozgássá.

A hajtásláncunk a következő elemekből épül fel:

- $1 \mathrm{db}$ pneumatikus munkahenger

○ munkahenger-rögzítés

○ $1 \mathrm{db}$ fogaskerék-fogasléc hajtómü

○ hajtómü-rögzítés

○ sebességváltó

\subsection{A pneumatikus munkahenger}

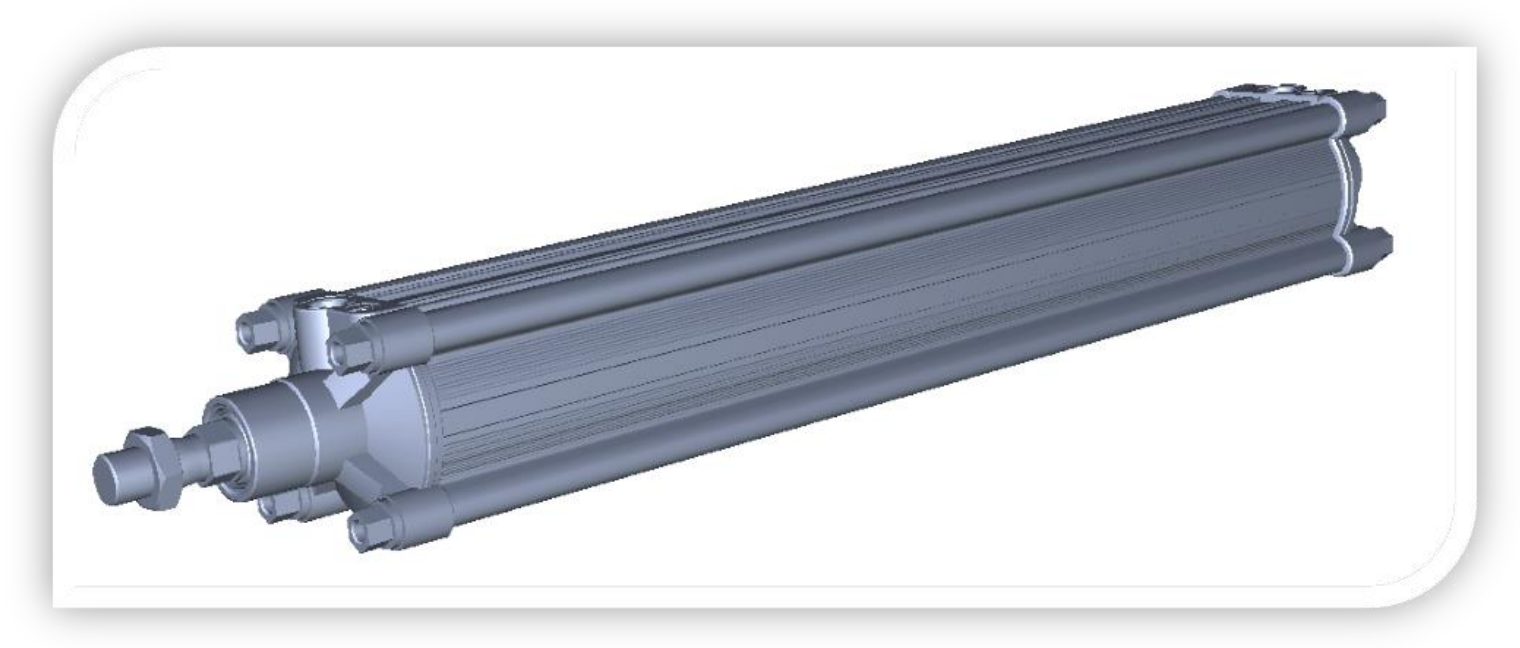

\section{2. ábra. Pneumatikus munkahenger}

A sürített levegő energiáját a pneumatikus munkahenger alakítja át mozgási energiává. A választásunk egy $80 \mathrm{~mm}$ dugattyúátmérővel és $500 \mathrm{~mm}$-es dugattyúúttal rendelkező PRA típusú hengerre esett (2. ábra). Ennek a hengernek a kitolásnál kifejtett ereje 3165 N, behúzásnál 2855 N. Ez kellő eröt biztosít, viszonyleg kis levegőfogyasztás mellett.

\subsection{A munkahenger-rögzítés}

A munkahenger-rögzítés feladata, hogy a munkahenger hengerét egy helyben tartsa, így a dugattyú mozgásai mind a hengerhez képest menjenek végbe. A munkahenger rögzítéséhez lézervágott acéllemezeket terveztem, melyek a vázban, külön a munkahengernek kialakított kosárban biztosítják a rögzítést. A hegesztett váz, illetve a rögzítöfuratok gyártási pontatlanságát úgy kívántam kiküszöbölni, hogy a felfogató lemezekkel a munkahenger állítható legyen a vázon belül, így precízen beállítható helyzete a hajtáslánc többi eleméhez képest is. 
Az állíthatóságot a lemezeken elhelyezett hornyok hivatottak biztosítani (3. ábra).
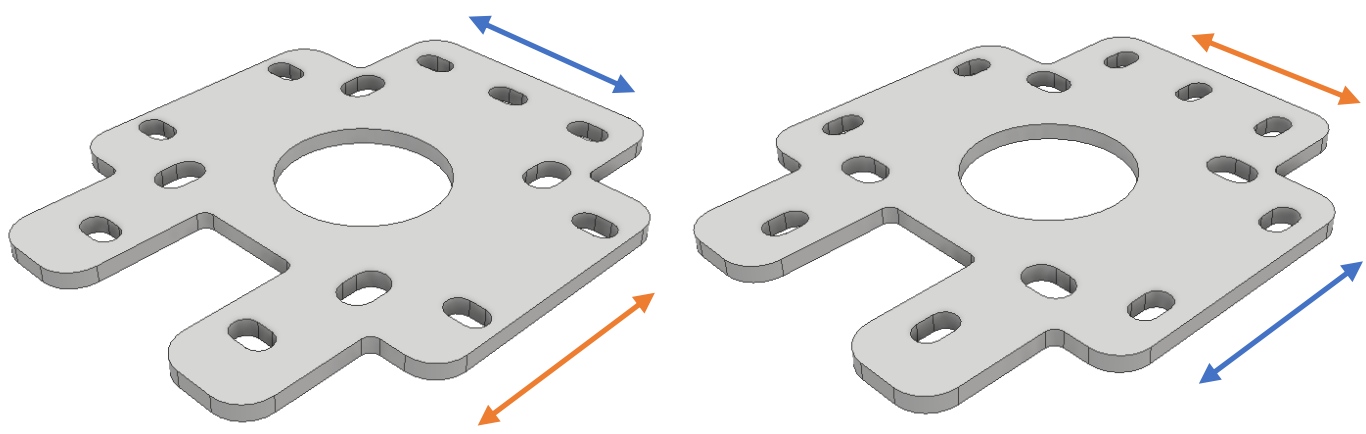

3. ábra. Allithatóság iránya a vázon, a henger felfogató hornyainak állithatósága

\subsection{A hajtáslánc helye a pneumobilon belül}

A pneumobilon belül a hajtás elhelyezését a 4 . ábra mutatja.

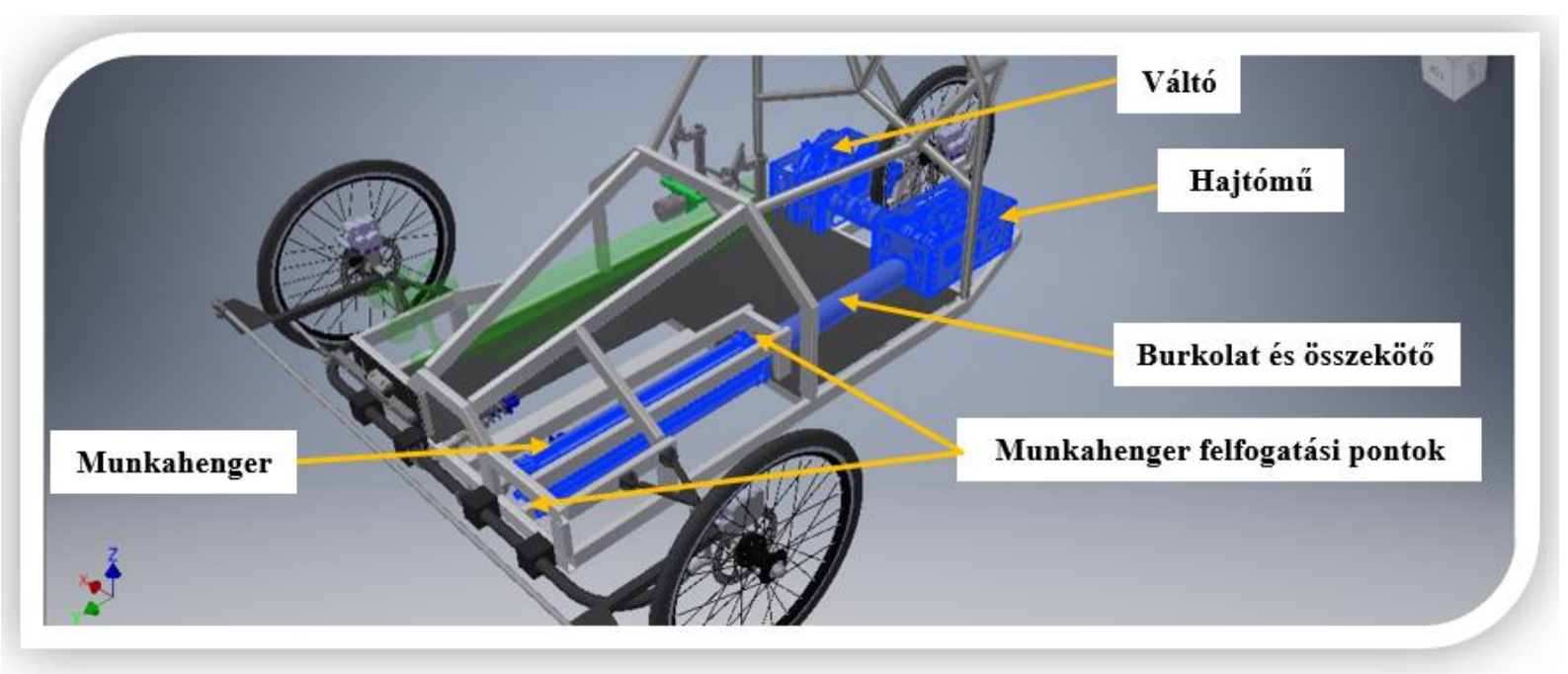

4. ábra. A hajtáslánc részeinek elhelyezése a pneumobilban

\subsection{A hajtómú müködési elve}

$1 \mathrm{db}$ munkahengerrel hajtjuk meg a jármủvet. Ez a henger lineáris mozgás előállítására képes. A hajtásláncban nekünk ezt forgómozgássá kell alakítanunk. Ezt egy fogaskerék-fogasléc hajtóművel valósítjuk meg, amely a lineáris alternáló mozgást egy fogaskerék - fogasléc kapcsolattal alakítja forgómozgássá.

Hogy a henger mind a két munkaütemét ki tudjuk használni az autó meghajtására, szükségünk van $2 \mathrm{db}$ szabadonfutóra (5. ábra), melyek az egyik forgási irányban átviszik az előállított nyomatékot, a másik forgási irányban viszont szabad elfordulást biztosítanak (így a szabad elfordulás forgási irányában csak megtámasztási feladatot látnak el). Ezek a fötengelyen egy külön erre a célra kialakított kosárban kapnak helyet. Ezek mellé a korábbi verziókban egy-egy csapágyat is beépítettünk, mivel ezeket az alkatrészeket elsősorban nem megtámasztásra tervezték. 
A henger első ütemében (kitolás) (5. és 7. ábra, és az ábrák jelölései), amikor a henger kitolja a dugattyúrudat és vele a hozzá rögzített fogaslecet (Fogasléc), a második nyeleskerék (Nyeleskerék_2) egyik oldalán reteszelt fogaskerék (Fogaskerék_2) meghajtja a fötengelyen (Fötengely) elhelyezett fogaskereket (Fogaskerék_3.1), amely a szabadonfutó segítségével forgatja meg a fötengelyt. Eközben a fordítókerék (Fordítókerék) csapágyazása, valamint a másik szabadonfutó, biztosítják, hogy a hajtómü ne feszüljön be és ne jöjjön létre ellentétes forgásirányú nyomatékátvitel.

A henger második ütemében (visszahúzás) (5. és 7. ábra, és az ábrák jelölései), amikor a henger visszahúzza dugattyúrudat és a hozzá rögzített fogaslecet (Fogasléc), ekkor az első nyeleskeréken (Nyeleskerék_1) reteszelt fogaskerék (Fogaskerék_1) a második nyeleskeréken található fordítókeréken (Fordítókerék) keresztül hajtja meg a fötengelyen lévő fogaskereket (Fogaskerék_3.2), ez utóbbi pedig a szabadonfutó segítségével forgatja a fötengelyt. Így biztosítva az egyirányúsítást (a fötengely mindig egy irányba forog a henger munkaütemének irányától függetlenül). A fogaslécet egy lineáris vezetékkel támasztottuk meg, melyre két lineáris vezetőkocsi került. Az ilyen lineáris vezetékeket jellemzően úgy alkalmazzák, hogy a vezeték áll, és a vezetőkocsi mozdul el, de az esetünkben a vezetőkocsik vannak rögzítve a hajtómü alapján. A két kocsira a pontosabb megvezetés érdekében volt szükség. Ezzel rengeteg helyet takarítottunk meg hiszen csak a mozgó vezetéknek kell elférnie.

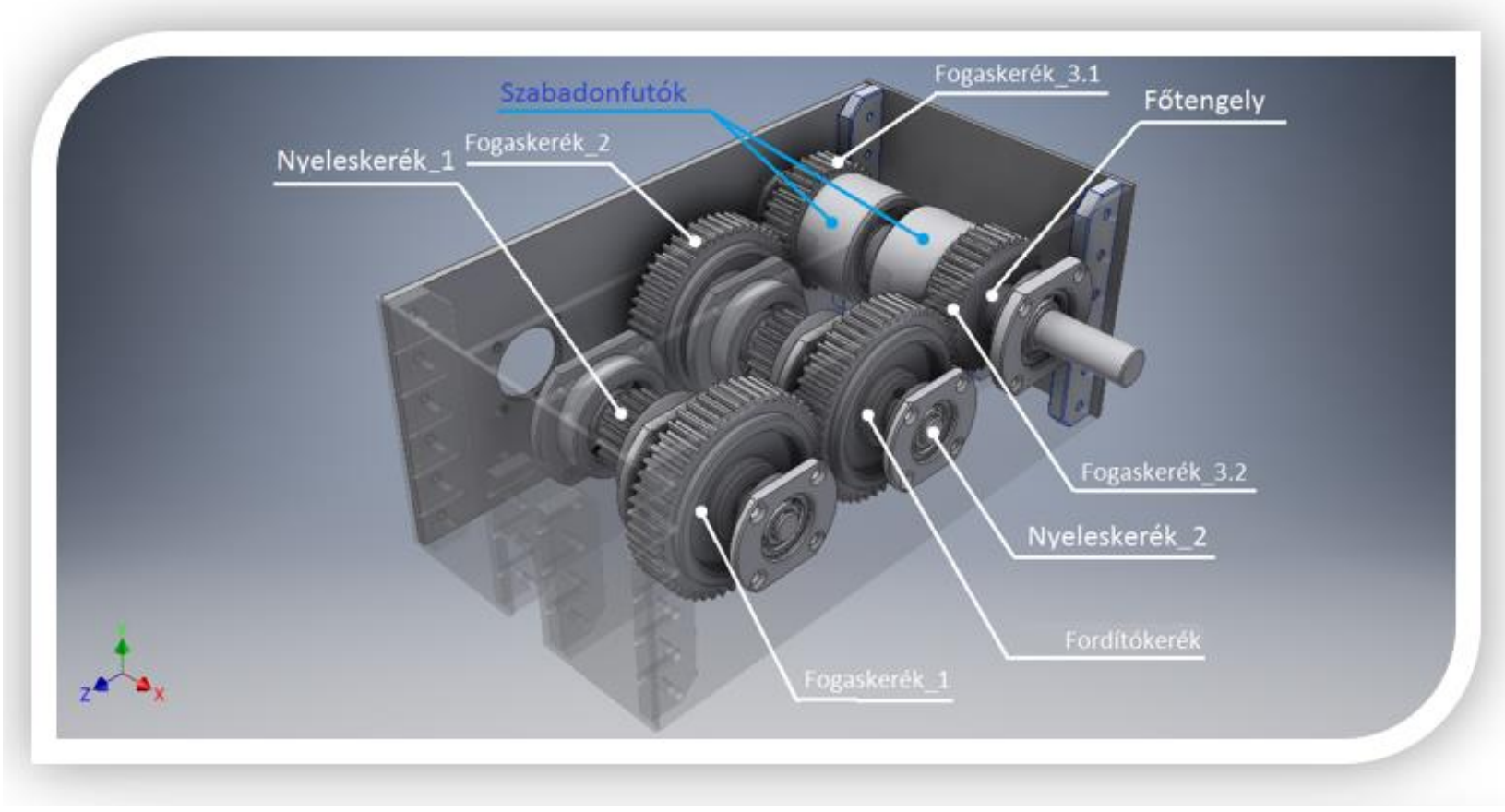

5. ábra. A hajtómü felépitése

\subsection{Forgásirányok és kinematikai ábra}

A 6. ábra a forgásirányokat mutatja be a dugattyúmozgás különböző irányainál, a 7. és a 8. ábra a rendszer kinematikai ábrái. 


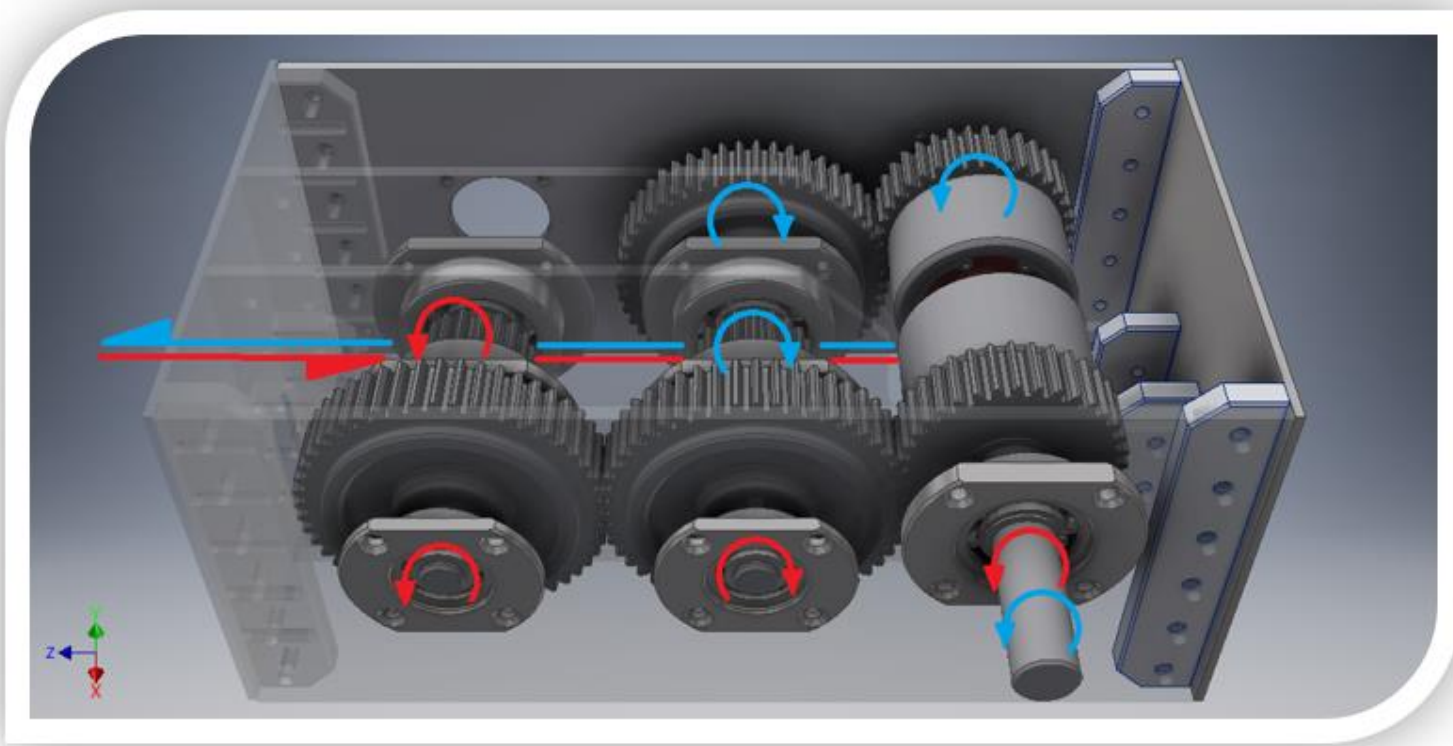

6. ábra. Forgásirányok

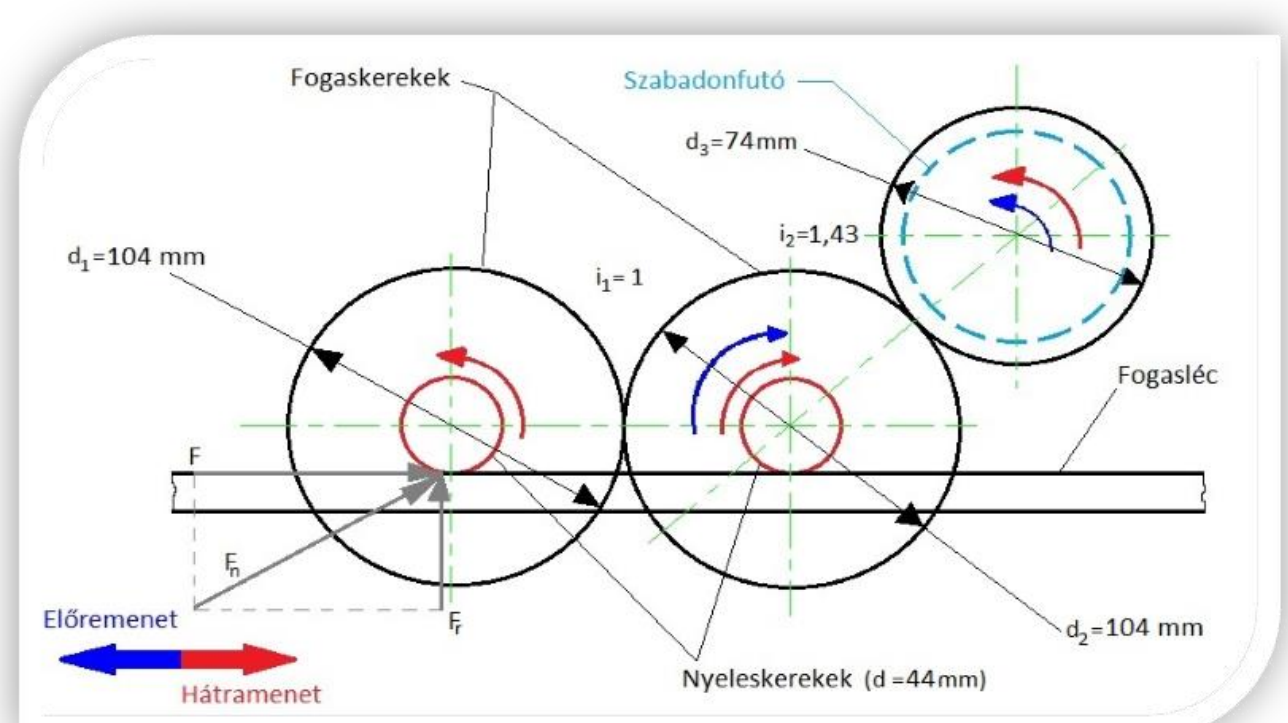

7. ábra. Kinematikai ábra 1 


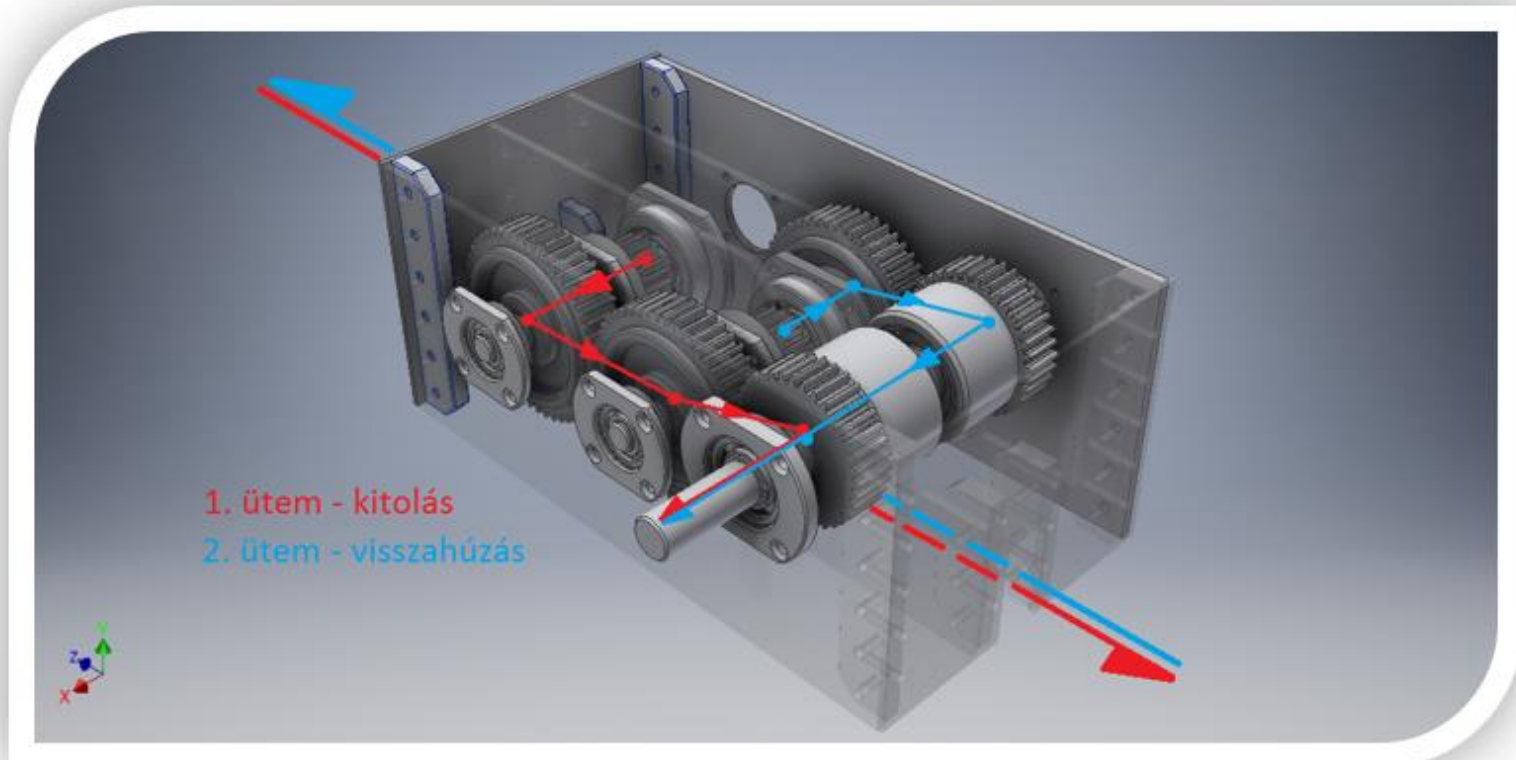

8. ábra. Kinematikai ábra 2

\subsection{Innovatív megoldások}

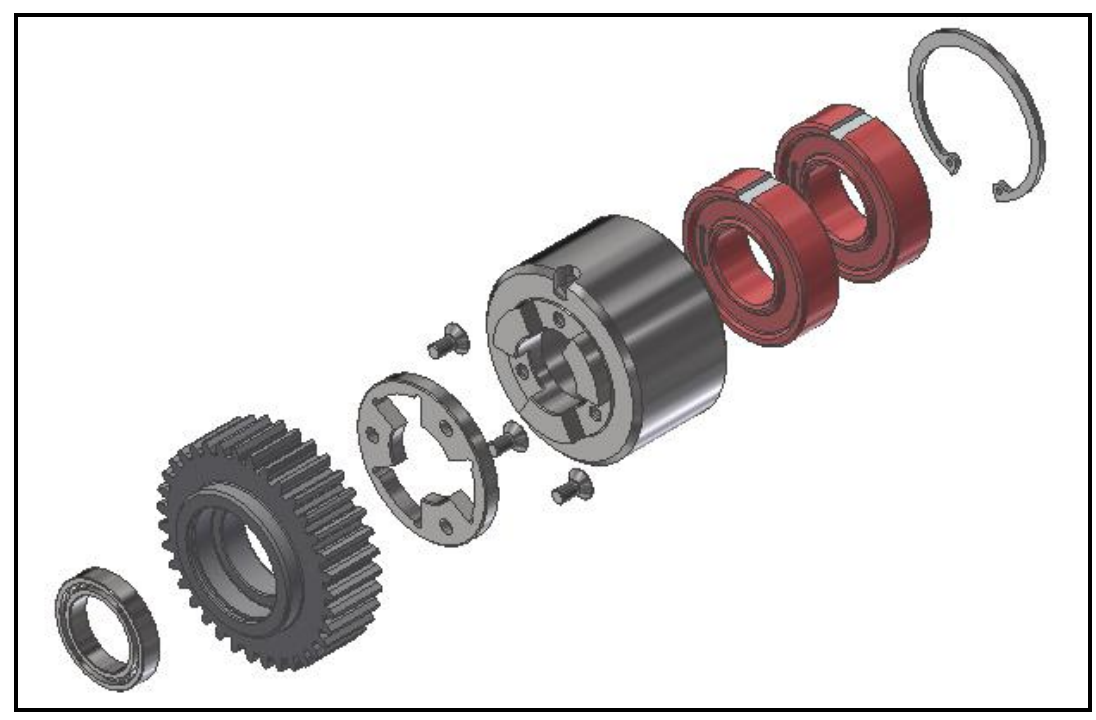

9. ábra. A szabadonfutó-kosarak robbantott ábrája

Az átmérők és a befoglaló méretek minimalizálásának érdekében a fötengelyen a szabadonfutók egy külön kosárban, a fogaskerék mellett kaptak helyet. A kinematikai kapcsolatot egy körmös tengelykapcsoló biztosítja, melynek az egyik fele a kosárból lett kimunkálva, másik oldala pedig, egy szikraforgácsolt lemezalkatrész, amely a fogaskerékben kialakított zsebben kapott helyet. Ezt süllyesztett 
fejű, 12.9 szilárdságú M5-ös csavarokkal rögzítettük, a kilazulás ellen közepes szilárdságú menetrögzítőt is alkalmaztunk.

A hajtómű korábbi verziójában egy szabadonfutó volt oldalanként, ebbe a megoldásba egy helyett két darab szabadonfutó (9. ábra) került be kosaranként. Így elhagyhattunk egy csapágyat, mivel a szabadonfutóban található egy golyósor is, és a gyártó ajánlása szerint, ha két darabot építünk be, elhagyhatjuk a csapágyazást. Továbbá a két szabadonfutóval az átvihető terhelést is növeltük kb. 70 százalékkal, figyelembe véve, hogy a gyártási pontatlanságok és a nagyon kis reteszelési elfordulás miatt a két szabadonfutó nem egyformán viszi át a terhelést.

A fogaskerékbe került egy csapágy a megfelelő megvezetés biztosítása érdekében.

\section{5. Összefoglalás}

A hajtómü ezekkel a megoldásokkal 342 fordulat/perc mellett $42 \mathrm{Nm}$-es nyomatékot képes elóállítani pusztán sürített levegő felhasználásával.

Figyelembe véve, hogy egy, már a korábbi években bevált megoldásból indultunk ki, de az innovatív megoldásokkal az össztömeg és a beépítési méret csökkent, elmondható, hogy pneumobilunk hajtásláncába egy egyedi, kompakt és hatékony hajtómü került beépítésre.

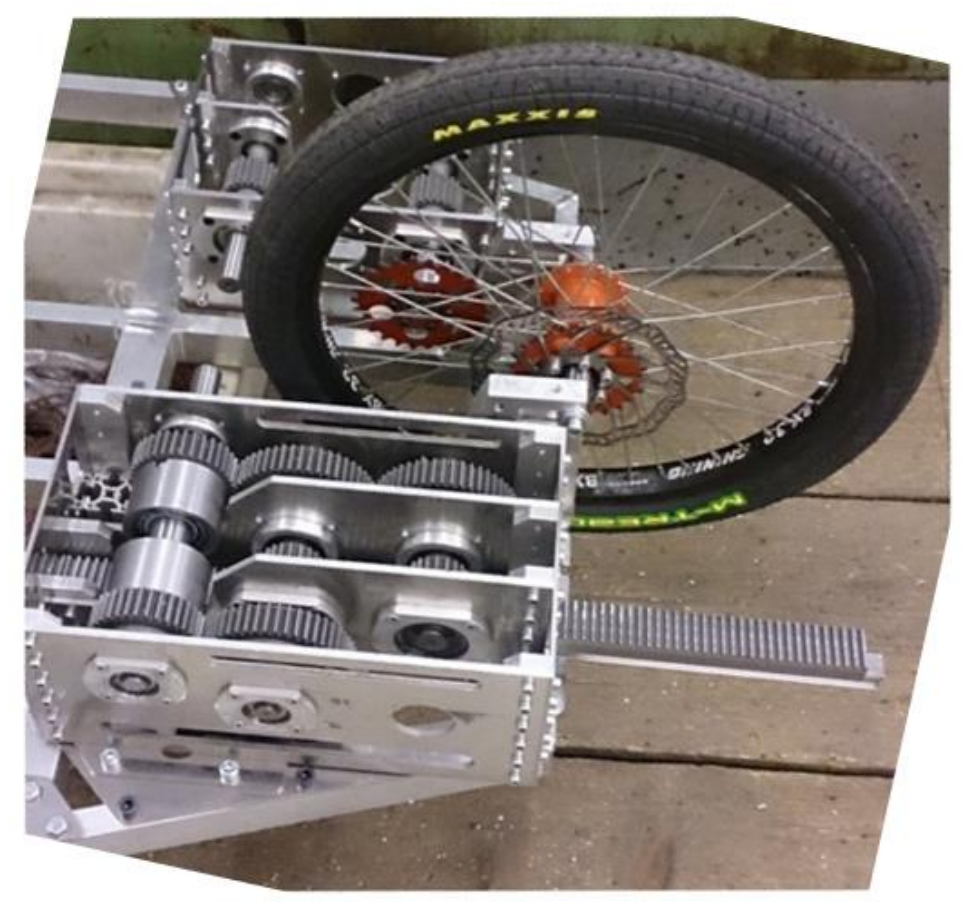

10. ábra. A beépitett kész hajtómü

A versenyen szereplő csapatok közül sokan alkalmaznak fogaskerék-fogasléc hajtóműveket. Ezek egyszerü, de jó hatásfokkal működő megoldások, igazodnak a pneumobilok igényeihez (pl.: alacsony fordulatszám, nagy nyomaték, kis beépítési méret, alacsony tömeg).

A tervezés során, mérlegelés után, én is ezt a koncepciót választottam, de igyekeztem egy olyan hajtásláncot építeni, amely kihasználja a munkahengerek előnyeit, és igyekszik kompenzálni azok 
hátrányait. Az egyedi tervezés lehetővé teszi, hogy igényeinknek megfelelő hajtáslánc kerüljön a pneumobilunkba.

A hajtáslánc folyamatosan finomításokon esett át az évek során, de végül, egy olyan konstrukció épülhetett meg, amely pontos megvezetést, kis beépítési méretet és tömeget képvisel, megbízható müködéssel és nagy átvihető terhelésekkel rendelkezik.

Ugyanakkor figyelembe kellett vennem, mind a tervezés mind a kivitelezés során, hogy csapatunk erőforrásai és az egyedi alkatrészek gyártásának lehetőségei korlátozottak, így törekedtem az egyszerü és olcsó, így számunkra is megvalósítható konstrukcióra.

\section{Köszönetnyilvánítás}

A cikkben ismertetett kutató munka az EFOP-3.6.1-16-2016-00011 jelü „Fiatalodó és Megújuló Egyetem - Innovativ Tudásváros - a Miskolci Egyetem intelligens szakosodást szolgáló intézményi fejlesztése" projekt részeként - a Széchenyi 2020 keretében - az Európai Unió támogatásával, az Európai Szociális Alap társfinanszírozásával valósul meg.

\section{Irodalom}

[1] Filepkó, M. Bihari, J. Kétfokozatú sebességváltó tervezése alternatív hajtású jármúvekhez. Multidiszciplináris tudományok, 2019, 9(2):3-7. https://doi.org/10.35925/j.multi.2019.2.1

[2] https://hu.wikipedia.org/wiki/Munkahenger, hozzáférés dátuma: 2019.12.10.

[3] https://hu.wikipedia.org/wiki/Pneumatika, hozzáférés dátuma: 2019.12.10.

[4] Aventics GmbH. Competition rules 2020, XIII. International Aventics Pneumobile Competition 2020, Eger, 2019.

[5] Bihari, J. Pneumobile competition and education, Advanced Engineering 2012, 2(1):125-134.

[6] Kelemen, L. Studying through the Pneumobile competition, In: Pokorádi, László (szerk.) Proceedings of the 1st Agria Conference on Innovative Pneumatic Vehicles - ACIPV 2017

[7] Kelemen, L. A pneumobil verseny 10 éve a Miskolci Egyetemen, GÉP 2017, 68(4):21-24. 